\title{
PENGARUH KOMPENSASI TERHADAP KEPUASAN KERJA PADA DINAS SOSIAL KABUPATEN LAMPUNG BARAT
}

\author{
Sodirin ${ }^{(1)}$, Nurmina $^{(2)}$ \\ Fakultas Ekonomi Universitas Sang Bumi Ruwa Jurai \\ sodirin@fe.saburai.ac.id,nurmina_bdl@gmail.com
}

\begin{abstract}
Abstrak. Kompensasi sangat mempengaruhi kinerja pegawai, jika kompensasi yang diberikan oleh dinas/satker sesuai dengan pekerjaan yang dikerjakan oleh pegawai, maka kinerja pegawai dapat meningkat. Obyek Penelitian adala Dinas Sosial Kabupaten Lampung Barat yang Beralamatkan di Jl. Teratai No. 08 Way Mengaku Komplek Perkantoran Pemda Lampung Barat. Adapun masalah yang ada pada kantor ini kompensasi yang di dapat belum sesuai dengan kebutuhan pegawai kepuasan kerja. Tujuan dari penelitian ini adalah untuk mengetahui Pengaruh Kompensasi Terhadap Kepuasan kerja Pada Dinas Sosial Kabupaten Lampung Barat. Hipotesis yang diajukan dalam penelitian ini adalah "Kompensasi berpengaruh terhadap Kepuasan kerja Pada Dinas Sosial Kabupaten Lampung Barat". Pengumpulan data penelitian menggunakan teknik sampel penelitian dari 21 responden. Metode penelitian yang digunakan adalah analisis kualitatif dan analisis kuantitatif yaitu regresi linier sederhana. Berdasarkan hasil analisis diperoleh persamaan bahwa $\mathrm{Y}=$ $4,743+0,415(\mathrm{X})$. Hasil pengujian menggunakan rumus $\mathrm{t}$ student, menunjukkan bahwa $\mathrm{t}_{\text {hitung }} 4,855>\mathrm{t}_{\text {tabel }}$ 2,085, berarti Ho ditolak dan Ha diterima, dengan demikian hipotesis yang diajukan dapat diterima.
\end{abstract}

Kata kunci: Kepuasan kerja, Kompensasi, Kinerja, Pegawai.

\section{PENDAHULUAN}

Pemerintah menyadari pentingnya pembangunan dibidang kesejahteraan sosial, untuk mengupayakan agar berbagai masalah sosial seperti kemiskinan, keterlantaran, kecacatan, ketunaan social, penyimpangan perilaku serta korban bencana dapat ditangani secara terpadu dan berkesinambungan. Pemberdayaan sosial merupakan salah satu dari empat intervensi kesejahteraan sosial yang diarahkan untuk masyarakat yang mengalami masalah kesejahteraan sosial dan tidak berdaya agar mereka mampu memenuhi kebutuhan dasarnya. Salah satu lingkup pemberdayaan sosial adalah keluarga terutama fakir miskin.

Selanjutnya kepuasan kerja (job satisfaction) adalah keadaan emosional yang menyenangkan atau tidak menyenangkan dengan mana para pegawai memandang pekerjaan mereka. Kepuasan kerja mencerminkan perasaan seseorang terhadap pekerjaannya. Ini nampak dalam sikap positif pegawai terhadap pekerjaan dan segala sesuatu yang dihadapi dilingkungan kerjanya.

Keith Davis dalam Mangkunegara Prabu AA Anwar (2011) mengemukakan bahwa, "job satisfaction is the favorableness or unfavorableness with employees view their work" atau kepuasan kerja adalah perasaan menyokong atau tidak menyokong yang dialami karyawan dalam bekerja (Anwar, 2011). Dari pendapat tersebut perasaan yang berhubungan dengan pekerjaan melibatkan aspek-aspek seperti upah atau gaji yang diterima, kesempatan pengembangan karir, hubungan dengan pegawai lainnya, penempatan kerja, jenis pekerjaan, struktur organisasi, mutu pengawasan.

Konsekuensi dari kepuasan kerja, Seperti sudah dijelaskan pada bagian sebelumnya mengenai kepuasan kerja, 
maka beberapa konsekuensi kepuasan kerja dapat dirangkum menjadi kepuasan dan Imbalan atau kompensasi, Suatu penelitian meta analisis yang dilakukan oleh A J Kinicki, dkk (2010) meliputi 9 hasil analisis yang melibatkan 2.237 orang pekerja mengungkapkan ada hubungan yang positif dan signifikan antara imbalan dan kepuasan kerja. Karena kepuasan dengan pengawasan berkorelasi secara signifikan dengan imbalan atau kompensasi, para manager disarnkan untuk mempertimbangkan bagaimana perilaku mereka mempengaruhi kepuasan kerja. Para pemimpin secara potensial meningkatkan motivasi para kpegawi melalui berbagai usaha untuk meningkatkan kepuasan kerja.

Kepuasan dan Keterlibatan dalam Pekerjaan, Keterlibatan dalam pekerjaan merupakan keterlibatan individu dengan peran dalam pekerjaannya. Suatu meta analisis yang melibatkan 27.925 responden dari 87 penelitian yang berbeda menunjukkan bahwa keterlibatan dalam pekerjaan memiliki keterkaitan dengan kepuasan kerja (Brown, 2012). Berdasarkan meta analisis yang mencakup 6.746 orang yang terdiri dari 28 penelitian terpisah mengungkapkan adanya hubungan yang positif dan signifikan antara perilaku sebagai anggota organisasi yang baik dengan kepuasan (Organ dan Ryan, 2010).

Kompensasi sangat mempengaruhi kinerja pegawai, jika kompensasi yang diberikan sesuai dengan pekerjaan yang dikerjakan oleh pegawai, maka kinerja pegawai dapat meningkat. Menurut Husein Umar dalam Sunyoto (2012) menyatakan bahwa salah satu cara manajemen untuk meningkatkan kinerja para pegawai adalah melalui imbalan.

Kompensasi di definisikan sebagai sesuatu yang di terima oleh pegawai sebagai balas jasa untuk jasa mereka. Kinerja dianggap sesuatu yang penting, baik bagi perusahaan maupun bagi pegawai itu sendiri. Tentu saja kegiatan-kegiatan dapat diselesaikan tepat waktu dan tujuan dapat dicapai dengan baik. Apabila seorang pegawai menganggap bahwa kompensasi yang diberikan sesuai dengan yang pegawai harapkan, maka akan dapat memotivasi pegawai untuk meningkatkan kinerjanya.

Pemberian kompensasi merupakan suatu biaya yang harus dikeluarkan oleh pihak instansi/satker kepada para pegawainya.Oleh karena itu pihak instansi harus melakukan suatu penilaian yang teliti mengenai produktifitas kerja yang dihasilkan oleh tiap-tiap pegawai tersebut. Hal tersebut dilaksanakan oleh pihak instansi karena instansi/satker tersebut menghendaki adanya suatu produktifitas kerja yang maksimal dari imbalan yang mereka keluarkan.

Demikian juga dengan Dinas Sosial Kabupaten Lampung Barat untuk mengarahkan dan mengoptimalkan segala potensi yang dimiliki oleh Dinas Sosial dan mengupayakan sumberdaya lainnya untuk terlibat secara aktif dalam pelaksaanaan program-program dan kegiatan yang telah direncanakan untuk mencapai tujuan pembangunan daerah. Berdasarkan fenomena tersebut, maka penulis bermaksud meneliti secara lebih mendalam mengenai kompensasi terhadap kepuasan kerja dalam judul: "Pengaruh Kompensasi Terhadap Kepuasan Kerja Pada Dinas Sosial Kabupaten Lampung Barat".

\section{KAJIAN TEORI}

\section{Pengertian Kompensasi}

Kompensasi merupakan salah faktor penting dan menjadi perhatian pada banyak organisasi dalam mempertahankan dan menarik sumber daya manusia yang berkualitas. Menurut I Komang Ardana (2012) "Kompensasi adalah segala sesuatu yang diterima oleh karyawan sebagai balas jasa atas kontribusinya kepada perusahaan atau organisasi" . Kompensasi dapat berupa 
gaji dan upah. Kompensasi bersifat financial dan non financial, sedangkan menurut Hasibuan (2012) "Kompensasi merupakan imbalan yang dibayarkan kepada karyawan atas jasa yang mereka sumbangkan pada pekerjaannya".

Setiap perusahaan memiliki indikator yang berbeda-beda dalam proses pemberian kompensasi untuk karyawan. Hasibuan (2012) mengemukakan, secara umum ada beberapa indikator kompensasi, yaitu:

1. Gaji adalah balas jasa dalam bentuk uang yang diterima karyawan sebagai konsekuensi dari kedudukannya sebagai seorang karyawan yang memberikan sumbangan tenaga dan pikiran dalam mencapai tujuan perusahaan.

2. Upah adalah imbalan finansial langsung yang dibayarkan kepada karyawan berdasarkan jam kerja, jumlah barang yang dihasilkan atau banyaknya pelayanan yang diberikan.

3. Insentif adalah imbalan langsung yang dibayarkan kepada karyawan karena kinerja melebihi standar yang ditentukan.

4. Bonus adalah pembayaran sekaligus yang diberikan karena memenuhi sasaran kinerja.

5. Fasilitas kantor adalah sarana yang diberikan perusahaan guna untuk kelangsungan kinerja karyawan.

6. Tunjangan adalah kompensasi yang diberikan perusahaan kepada para karyawannya tersebut dianggap telah ikut berpartisipasi dengan baik dalam mencapai tujuan perusahaan.

7. Jaminan sosial, suatu perlindungan bagi tenaga kerja dalam bentuk santunan berupa uang sebagai pengganti sebagian dari penghasilan yang hilang atau berkurang sebagai akibat peristiwa atau keadaan yang dialami oleh tenaga kerja berupa kecelakaan kerja, sakit, bersalin, hari tua dan meninggal.

\section{Pengertian Kepuasan Kerja}

Setiap orang yang bekerja mengharapkan memperoleh kepuasan dari tempatnya bekerja. Pada dasarnya kepuasan kerja merupakan hal yang bersifat individual karena setiap individu akan memiliki tingkat kepuasan yang berbedabeda sesuai dengan nilai-nilai yang berlaku dalam diri setiap individu. Semakin banyak aspek dalam pekerjaan yang sesuai dengan keinginan individu, maka semakin tinggi tingkat kepuasan yang dirasakan.

Menurut Kreitner dan Kinicki dalam Hasibuan (2011) kepuasan kerja adalah "suatu efektifitas atau respon emosional terhadap berbagai aspek pekerjaan". Davis dan Newstrom dalam Susilo Martoyo (2013) mendeskripsikan "kepuasan kerja adalah seperangkat perasaan pegawai tentang menyenangkan atau tidaknya pekerjaan mereka". Menurut Robbins dalam Sunyoto (2013) kepuasan kerja adalah "sikap umum terhadap pekerjaan seseorang yang menunjukkan perbedaan antara jumlah penghargaan yang diterima pekerja dan jumlah yang mereka yakini seharusnya mereka terima". Kepuasan kerja merupakan respon afektif atau emosional terhadap berbagai segi atau aspek pekerjaan seseorang sehingga kepuasan kerja bukan merupakan konsep tunggal. Seseorang dapat relatif puas dengan salah satu aspek pekerjaan dan tidak puas dengan satu atau lebih aspek lainnya.

\section{Faktor-faktor yang Mempengaruhi Kepuasan Kerja}

Ada 5 (lima) faktor yang dapat mempengaruhi kepuasan kerja menurut Kreitner dan Kinicki dalam Hasibuan (2011) yaitu sebagai berikut :

1. Pemenuhan kebutuhan (Need fulfillment)

Kepuasan ditentukan oleh tingkatan karakteristik pekerjaan memberikan 
kesempatan pada individu untuk memenuhi kebutuhannya.

\section{Perbedaan (Discrepancies)}

Kepuasan merupakan suatu hasil memenuhi harapan. Pemenuhan harapan mencerminkan perbedaan antara apa yang diharapkan dan apa yang diperoleh individu dari pekerjaannya. Bila harapan lebih besar dari apa yang diterima, orang akan tidak puas. Sebaliknya individu akan puas bila menerima manfaat diatas harapan.

\section{Pencapaian nilai (Value attainment)}

Kepuasan merupakan hasil dari persepsi pekerjaan memberikan pemenuhan nilai kerja individual yang penting.

\section{Keadilan (Equity)}

Kepuasan merupakan fungsi dari seberapa adil individu diperlakukan di tempat kerja.

5. Komponen genetik (Genetic components) Kepuasan kerja merupakan fungsi sifat pribadi dan faktor genetik. Hal ini menyiratkan perbedaan sifat individu mempunyai arti penting untuk menjelaskan kepuasan kerja disampng karakteristik lingkungan pekerjaan.

\section{Meningkatkan Kepuasan Kerja}

Menurut Riggio dalam Mangkunegara Prabu AA Anwar (2013), peningkatan kepuasan kerja dapat dilakukan dengan cara sebagai berikut:

1. Melakukan perubahan struktur kerja, misalnya dengan melakukan perputaran pekerjaan (job rotation), yaitu sebuah sistem perubahanpekerjaan dari salah satu tipe tugas ke tugas yang lainnya (yang disesuaikan dengan job description).

2. Melakukan perubahan struktur pembayaran, perubahan system pembayaran ini dilakukan dengan berdasarkan pada keahliannya (skill- based pay), yaitu pembayaran dimana para pekerja digaji berdasarkan pengetahuan dan keterampilannya daripada posisinya di perusahaan.

3. Pemberian jadwal kerja yang fleksibel, dengan memberikan kontrol pada para pekerja mengenai pekerjaan sehari-hari mereka, yang sangat penting untuk mereka yang bekerja di daerah padat, dimana pekerja tidak bisa bekerja tepat waktu atau untuk mereka yang mempunyai tanggung jawab pada anakanak. Compressed work week (pekerjaan mingguan yang dipadatkan), dimana jumlah pekerjaan per harinya dikurangi sedang jumlah jam pekerjaan per hari ditingkatkan. Para pekerja dapat memadatkan pekerjaannya yang hanya dilakukan dari hari Senin hingga Jum'at, sehingga mereka dapat memiliki waktu longgar untuk liburan. Cara yang kedua adalah dengan sistem penjadwalan dimana seorang pekerja menjalankan sejumlah jam khusus per minggu (Flextime), tetapi tetap mempunyai fleksibilitas kapan mulai dan mengakhiri pekerjaannya.

4. Mengadakan program yang mendukung, perusahaan mengadakan programprogram yang dirasakan dapat meningkatkan kepuasan kerja para karyawan, seperti; health center, profit sharing, dan employee sponsored child care.

\section{METODE PENELITIAN}

\section{Objek Penelitian}

Objek penelitian ini adalah pegawai di Dinas Sosial Kabupaten Lampung Barat, yang beralamat di Jln.Mawar No.3 Komplek Pemda Liwa Lampung Barat. Penelitian ini di laksanakan dari bulan April sampai dengan Agustus 2018. 


\section{Metode dan Teknik Pengumpulan Data}

Dalam penelitian ini jenis data yang diperlakukan adalah :

\section{a. Data Primer}

Data primer merupakan data dasar yang akan diperoleh langsung tanpa perantara orang atau lembaga lain sebagai pihak ketiga. Data primer ini diperoleh dengan wawancara melalui responden dengan menggunakan daftar pertanyaan.

\section{b. Data Sekunder}

Data skunder merupakan data yang diperoleh melalui orang lain yang berhubungan dengan permasalahan yang dipecahkan. Data sekunder ini diperoleh melalui cara studi dokumenter yaitu mengumpulkan dan mempelajari brosurbrosur serta dokumen organisasi.

\section{Sampel dan Populasi}

Sampel penelitian adaalah sebagian dari populasi yang mewakili sifat dan karakter yang sama. Untuk menentukan banyak sampel, peneliti menggunakan pedoman dari pendapat Suharsimi Arikunto (2010). Maka apabila subyeknya kurang dari 100, lebih baik diambil semua sehingga penelitiannya merupakan penelitian populasi. Selanjutnya jika jumlah subyeknya besar, dapat diambil 10\% - 15\% atau $20 \%-25 \%$ atau lebih. Dalam penelitian ini merupakan penelitian sampel. Adapun jumlah sampel yang diambil adalah seluruh populasi pegawai Dinas Sosial Kabupaten Lampung Barat yang berjumlah 21 orang pegawai.

\section{Metode Analisis Data}

Untuk pengolahan data dalam bentuk tabulasi hasil jawaban responden kemudian dilakukan analisis data melalui metode analisis secara kualitatif dan analisa kuantitatif.
Analisis kualitatif merupakan analisis yang dinyatakan dalam bentuk uraian dan didasarkan pada data yang telah ada. Data kualitatif merupakan data berupa informasi yang kemudian dikaitkan dengan data lainnya sehingga memunculkan suatu kebenaran.

Analisis kuantitatif yang dilakukan berdasarkan data primer yang diperoleh dari penyebaran instrument (daftar pertanyaan) kepada sampel, dan untuk mengetahui pengaruh dari variabel bebas (independent variable) terhadap variabel terikat (dependent variable).

Persamaan Regresi Linear Sederhana menentukan persamaan regresi linear sederhana untuk $\mathrm{X}$ :

$$
Y=a+b X+e
$$

Keterangan:

$$
\begin{aligned}
& \mathrm{Y}=\text { Kepuasan kerja } \\
& \mathrm{a}=\text { Konstanta } \\
& \mathrm{b}=\text { Koefisien regresi } \mathrm{X} \\
& \mathrm{X}=\text { Kompensasi } \\
& \mathrm{e}=\text { Faktor kesalahan }
\end{aligned}
$$

Untuk mengetahui besarnya pengaruh, penghitungan koefisien korelasi tersebut kemudian dilanjutkan dengan Rumus Koefisien Determinasi atau Koefisien Penentu (KP):

$$
K P=(r)^{2} x 100 \%
$$

Untuk menguji secara hipotesis secara parsial digunakan Uji t dengan rumus :

$$
t_{\text {hitung }}=\frac{r \sqrt{N-2}}{\sqrt{1-r^{2}}}
$$

$$
\begin{array}{cl}
\text { Keterangan: } & \\
\mathrm{t}_{\text {hitung }} & =\text { Nilai } \mathrm{t} \\
\mathrm{r} & =\text { Koefisien Korelasi }
\end{array}
$$




$$
\mathrm{N} \quad=\text { Jumlah responden }
$$

Kriteria untuk Uji $\mathrm{t}$ adalah sebagai berikut :

a) Jika $t_{\text {hitung }}>t_{\text {tabel }}$ maka Ha diterima dan Ho ditolak.

b) Jika $t_{\text {hitung }} \leq \mathrm{t}_{\text {tabel }}$ maka Ha ditolak dan Ho diterima.

Taraf signifikan dalam penelitian ini digunakan $\alpha=0,05$ atau 5\%. Yang dimaksud dengan Hipotesis nol (Ho) dan Hipotesis alternatif $(\mathrm{Ha})$ adalah :

Ho $=\mathrm{r} \leq 0=$ Berarti tidak ada pengaruh kompensasi kerja terhadap kepuasan kerja $\mathrm{Ha}=\mathrm{r}>0=$ Berarti ada pengaruh kompensasi kerja terhadap kepuasan kerja (Sugiyono, 2008).

\section{HASIL DAN PEMBAHASAN}

Data penelitian yang telah dikumpulkan kemudian diolah untuk menguji kualitas data berupa uji validitas dan reliabilitas menunjukkan bahwa koefisien korelasi pearson moment untuk setiap item butir pertanyaan dengan skor total variabel kompensasi (X), dan kepuasan kerja (Y) signifikan pada tingkat signifikan $\alpha 0,05$. Dengan demikian dapat diinterprestasikan bahwa setiap item indikator instrumen masing-masing variabel tersebut valid.

\section{Uji Validitas}

Tabel 1. Hasil Uji Validitas Instrumen Variabel Kompensasi

\begin{tabular}{|c|c|c|c|}
\hline Indikator & $r$ hitung & $r$ tabel & Keterangan \\
\hline X11 & 0.945 & 0.514 & Valid \\
\hline X12 & 0.967 & 0.514 & Valid \\
\hline X13 & 0.967 & 0.514 & Valid \\
\hline X14 & 0.967 & 0.514 & Valid \\
\hline X15 & 0.850 & 0.514 & Valid \\
\hline X16 & 0.855 & 0.514 & Valid \\
\hline X17 & 0.945 & 0.514 & Valid \\
\hline
\end{tabular}

Berdasarkan Tabel 1. nilai $\mathrm{r}$ hitung kompensasi lebih besar dari r tabel (0.514), sehingga seluruh indikator dinyatakan valid.

Tabel 2. Hasil Uji Validitas Instrumen Variabel Kepuasan kerja

\begin{tabular}{|c|c|c|c|}
\hline Indikator & r hitung & $\mathrm{r}$ tabel & Keterangan \\
\hline Y11 & 0.882 & 0.514 & Valid \\
\hline Y12 & 0.949 & 0.514 & Valid \\
\hline Y13 & 0.959 & 0.514 & Valid \\
\hline Y14 & 0.876 & 0.514 & Valid \\
\hline
\end{tabular}

Berdasarkan Tabel 2. hasil perhitungan menunjukkan bahwa seluruh indikator untuk variabel kepuasan kerja adalah lebih besar dari $r$ tabel, sehingga seluruh indikator dinyatakan valid.

\section{Uji Reliabilitas Data}

Uji reliabilitas instrumen menggunakan rumus Cronbach Alpha $(\alpha)$ untuk masing-masing variabel adalah lebih besar dari 0,60. Demikian dapat disimpulkan bahwa item-item untuk masing-masing variabel adalah reliabel. Nilai reliabilitas konsistensi internal ditunjukkan dalam tabel diatas, untuk koefisien Alpha Cronbach dinyatakan reliabel karena lebih besar dari 0,60. Dengan demikian item pengukuran pada masing-masing indikator dalam variabelvariabel penelitian dinyatakan reliabel dan selanjutnya dapat digunakan dalam penelitan.

\section{Analisis Kuantitatif}

Dari pengolahan data statistik maka diperoleh persamaan regresi linier sederhana adalah $\mathrm{Y}=4.743+0.415(\mathrm{X})$. Nilai konstanta yang diperoleh sebesar 4.743, hal ini berarti bahwa jika variabel independen (imbalan) adalah bernilai nol, maka besarnya kepuasan kerja yang terjadi adalah 4.743. Nilai koefisien regresi variabel imbalan $(X)$ sebesar 0.415 , hal ini menunjukkan bahwa setiap kenaikan satu satuan imbalan internal akan 
mengakibatkan kepuasan kerja sebesar 0.415 .

Koefisien determinan $\left(\mathrm{R}^{2}\right)$ digunakan untuk mengetahui kontribusi variabel bebas dalam menjelaskan variabel terikat. Semakin besar nilai koefisien determinasi maka menunjukkan semakin besar pula pengaruh variabel terikat terhadap variabel bebas. Hasil pengujian menunjukkan bahwa nilai $R$ square sebesar 0.554 Nilai $R$ square ini menunjukkan bahwa besarnya kontribusi variabel independen terhadap variabel dependen adalah sebesar 55,4\%, sedangkan sisanya sebesar 44,6 \% ditentukan oleh variabel lain yang tidak teridentifikasi dalam penelitian ini.

Pengujian ini dilakukan untuk menjawab model kelayakan hipotesis penelitian. Pengujian dilakukan dengan menggunakan uji $\mathrm{t}$ pada tingkat kepercayaan $95 \%$ atau $\alpha$ sebesar 0.05 dari hasil output SPSS yang diperoleh, apabila $t_{\text {hitung }}>t_{\text {tabel. }}$. Maka model dinyatakan layak digunakan dalam penelitian ini dan sebaliknya apabila $t_{\text {hitung }}<t_{\text {tabel, }}$ maka model dikatakan tidak layak, atau dengan signifikan (Sig) $<0.05$ maka model dinyatakan layak digunakan dalam penelitian ini dan sebaliknya apabila signifikan (Sig) > 0.05 maka model dinyatakan tidak layak digunakan.

Hasil pengujian menjawab hipotesis yang menyatakan "kompensasi berpengaruh terhadap kepuasan kerja." Pengujian dilakukan dengan menggunakan uji t yang menunjukkan bahwa kompensasi berpengaruh terhadap kepuasan kerja. Pengujian dilakukan dengan menggunakan uji t pada tingkat keyakinan signifikansi $\alpha$ 0.05, dapat diketahui bahwa tingkat signifikansi sebesar $0.00<0.05$ dengan nilai $t_{\text {hitung }}>t_{\text {tabel }}$ yaitu $4.855>2.085$, dengan demikian hipotesis diterima yang berarti kompensasi berpengaruh terhadap kepuasan kerja.

\section{KESIMPULAN DAN SARAN}

\section{Kesimpulan}

Berdasarkan hasil penelitian dapat disimpulkan bahwa hasil pengujian menunjukkan nilai $R$ square sebesar 0.554 Nilai $R$ square ini menunjukkan bahwa besarnya kontribusi variabel independen terhadap variabel dependen adalah sebesar $55,4 \%$, sedangkan sisanya sebesar $44,6 \%$ ditentukan oleh variabel lain yang tidak teridentifikasi dalam penelitian ini. Pengujian menjawab hipotesis yang menyatakan "Kompensasi berpengaruh terhadap kepuasan kerja pada Dinas Sosial Kabupaten Lampung Barat." Pengujian dilakukan dengan menggunakan uji t yang menunjukkan bahwa kompensasi berpengaruh terhadap kepuasan kerja. Dari hasil diketahui bahwa tingkat signifikansi sebesar $0.00<0.05$ dengan nilai $t_{\text {hitung }}>$ $\mathrm{t}_{\text {tabel }}$ yaitu $4.855>2.085$, dengan demikian hipotesis diterima yang berarti kompensasi berpengaruh terhadap kepuasan kerja pada Dinas Sosial Kabupaten Lampung Barat.

\section{Saran}

Adapun saran yang diajukan peneliti adalah sebagai berikut:

1. Dinas Sosial Kabupaten Lampung Barat hendaknya mempertimbangan pemberian kompensasi dalam bentuk reward yang diberikan kepada pegawainya agar mereka semakin bersemangat untuk bekerja lebih baik.

2. Dinas Sosial Kabupaten Lampung Barat hendaknya memberikan tambahan insentif yang sesuai kepada prestasi kerja staf/pegawainya sehingga dapat bekerja dengan baik sesuai produktivitas dan semangat kerjanya

3. Dinas Sosial Kabupaten Lampung Barat hendaknya memberikan rewand kepada pegawainya sesuai dengan kemampuan 
dan kualitas yang dimiliki sesuai dengan kinerjanya..

\section{DAFTAR PUSTAKA}

Algifari. 2008. Metode Penelitian Bisnis. Cetakan Ke- 15. Bandung: CV. Alfabeta.

A J Kinicki, dkk dalam Hasibuan. 2010. Managemen Theory. Edisi 9. Jakarta: Salemba Empat.

Ferdinand. 2006. Manajemen Sumber Daya Manusia. Jakarta: Elex Media Kompetindo.

Hasibuan. 2012. Organisasi dan Motivasi. Jakarta: PT. Bumi Aksara. Jatmiko. Manajemen Stratejik. 2004. UMM Press.

Husein Umar dalam Sunyoto. 2012. Manajemen Sumber Daya Manusia Strategik. Jakarta: Ghalia Indonesia.

Mangkunegara Prabu AA Anwar. 2014. Sumber Daya Manusia. Jakarta: Salemba empat.

Organ dan Ryan dalam Mangkunegara Prabu AA Anwar. 2010. Journal Of Social And Politic.

Robbins.dalam Sunyoto. 2013. Organization Management. Alih bahasa. Djoerban Wahid. Jakarta: Penerbit Erlangga.

S, P, Brown, dalam Mangkunegara Prabu AA Anwar. 2012. Managing Productivity in Organization. Alih bahasa. Djoerban Wahid. Jakarta: Penerbit Erlangga.

Sugiyono. 2010. Metode Penelitian Bisnis. Cetakan Ke- 15. Bandung: CV. Alfabeta.
Tett dan Meyer dalam Sunyoto. 2003. Organization Management. Alih bahasa. Djoerban Wahid. Jakarta: Penerbit Erlangga.

Veithzal Rivai dalam Hasibuan. 2011. Professional Development For Education Management. USA: Open University Press.1 